\title{
JURNALISME BENCANA DAN RANGSANGAN EMOSIONAL STUDI HUBUNGAN JURNALISME BENCANA BANJIR SURAT KABAR SOLOPOS DENGAN RANGSANGAN EMOSIONAL MAHASISWA UNIVET BANTARA SUKOHARJO
}

\author{
Betty Gama \\ Program Studi Ilmu Komunikasi, \\ FISIP Universitas Veteran Bangun Nusantara \\ Jl. Letjen S. Humardani No. 1 Jombor Sukoharjo (Jateng) \\ Email: bettygama_62@yahoo.com
}

\begin{abstract}
Disaster journalism is aimed as how the media tells the disaster itself. Based on the data analysis toward the five (5) research variables, only the proximity variable that doesn't have relation to the university students emotional stimulus, with the significance score of $0.864>0,005$. Timeliness variable to the learners emotional stimulus with the significance score of $0.026<0.005$. Consequence variable toward the leaners emotional stimulus with significance score of $0.000<$ 0.005 , human interest variable towards the learners emotional stimulus with significance score of $0.000<0.005$ and magnitude variable toward learners emotional stimulus with significance score of $0.000<0.005$. Testing data is using correlation Tata Jenjang Spearmens ( $\mathrm{rs}$ ) / Spearmans Phase Order with $5 \%$ of trutworthiness. The sample of the research is the students at even semester of Veteran Bangun Nusantara University of Sukoharjo at academic year of 2007/2008 covering 98 students. Sampling technique which use is Proposional Simple Random Sampling.
\end{abstract}

Keywords: Journalistic, disaster.

\section{PENDAHULUAN}

Bagi media massa, bencana bisa menjadi peluang untuk dijadikan materi informasi yang tidak pernah kering, terutama karena kandungan nilai beritanya yang tinggi. Jurnalisme bencana dimaksudkan sebagai bagaimana media memberitakan bencana. Dalam kata "bagaimana memberitakan" terkandung dua dimensi yaitu dimensi proses dan hasil. Dimensi proses mengacu pada proses produksi berita-berita bencana sedangkan dimensi hasil mengacu pada berita-berita bencana yang dimuat atau disiarkan media (Eriyanto, 2001). Bencana tsunami di Aceh 2004, gempa bumi di Yogyakarta pada 27 Mei 2006, lumpur panas Lapindo di Sidoarjo yang belum terselesaikan hingga sekarang dan masih banyak lagi bencana yang melanda di berbagai daerah, dimana liputannya merupakan salah satu bentuk dari jurnalisme bencana.

Liputan intensif, interaktif dan langsung tentang bencana banjir di akhir tahun 2007 (26-31 Desember 2007) di Surakarta, menunjukkan momentum di mana media 
benar-benar menampakkan kekuatan agenda settingnya, sekaligus mempraktekkan hal baru yaitu jurnalisme bencana. Hampir seluruh media baik lokal maupun nasional berlomba-lomba memberitakan bencana banjir secara langsung dan eksklusif. Fungsi media berperan secara aktif baik media cetak maupun media elektronik. Media cetak seperti Solopos dengan liputan eksklusifnya menyajikan bencana banjir dan tanah longsor setiap harinya, sementara media elektronik seperti radio dan televisi dapat memberikan informasi hanya dalam hitungan detik. Hal yang tak kalah pentingnya dalam jurnalisme bencana yang terjadi ini adalah keterlibatan atau partisipasi masyarakat dalam memberikan informasi yang berkaitan dengan curah hujan dan banjir kepada media terutama media elektronik radio baik melalui telepon maupun SMS.

Terkait dengan liputan bencana, media massa akan selalu memberikan liputan yang terjadi bahkan yang terkini. Jika dicermati, liputan media lebih mengarah pada pemberitaan traumatik dan dramatik. Yang muncul dalam media adalah isak tangis, kesedihan, kekecewaan, jumlah korban dan kisah tragis lainnya dan semua itu memberi kesan mencekam. Jurnalisme bencana bukan hanya menyajikan informasi pada saat terjadi bencana tetapi juga informasi yang berkaitan dengan pemulihan atau recovery di wilayah banjï.

Melalui media, masyarakat mengetahui berbagai peristiwa bencana. Bagi masyarakat yang terkena korban bencana atau bukan, bencana merupakan peristiwa historis yang sangat membekas, secara psikologis dan sosial. Bagi masyarakat korban bencana, bekas psikologis ini sangat mendalam dan permanen, berupa traumatrauma tertentu. Bagi masyarakat yang bukan korban bencana, bekas psikologis ini berupa empati, kepedulian, juga rasa takut. Dengan demikian media mampu menghasilkan rangsangan-rangsangan tertentu pada diri individu seperti rasa takut, sedih, gembira dan sebagainya sebagai akibat dari pesan media massa. Weiss dalam Jalaluddin Rakhmat (2000) menemukan faktor-faktor yang mempengaruhi intensitas rangsangan emosional pesan media. Faktor-faktor itu, antara lain, suasana emosional (mood), skema kognitif, suasana terpaan, predisposisi individual dan tingkat identifikasi khalayak dengan tokoh dalam media massa. Kajian mengenai kaitan antara jurnalisme bencana banjir terhadap rangsangan emosional masyarakat amatlah dibutuhkan pada saat-saat sekarang mengingat akhir-akhir ini sering terjadi bencana alam dan apalagi wilayah Indonesia sendiri juga rawan terhadap bencana alam.

Populasi penelitian adalah mahasiswa Universitas Veteran Bangun Nusantara (Univet Bantara) Sukoharjo. Dalam penelitian ini penulis akan mencoba untuk mengetahui secara spesifik melalui pengamatan empirik tentang seberapa jauh hubungan antara jurnalisme bencana banjir media surat kabar Solopos dengan rangsangan emosional mahasiswa. Adapun perumusan masalah dalam penelitian ini adalah sebagai berikut:

1. Seberapa jauh hubungan antara nilai berita timeliness jurnalisme bencana banjir surat kabar Solopos dengan rangsangan emosional mahasiswa?

2. Seberapa jauh hubungan antara nilai berita proximity jurnalisme bencana banjir surat kabar Solopos dengan rangsangan emosional mahasiswa?

3. Seberapa jauh hubungan antara nilai berita consequence jurnalisme bencana banjir surat kabar Solopos dengan rangsangan emosional mahasiswa? 
4. Seberapa jauh hubungan antara nilai berita human interest jurnalisme bencana banjir surat kabar Solopos dengan rangsangan emosional mahasiswa?

5. Seberapa jauh hubungan antara nilai berita magnitude jurnalisme bencana banjir surat kabar Solopos dengan rangsangan emosional mahasiswa?

\section{PEMBAHASAN}

Hutchins Commission mengajukan 5 prasyarat sebagai syarat bagi pers yang bertanggungjawab kepada masyarakat, yaitu:

1. Media harus menyajikan berita-berita peristiwa sehari-hari yang dapat dipercaya, lengkap dan cerdas dalam konteks yang memberikannya makna. (Media harus akurat; mereka tidak boleh berbohong, harus memisahkan antara fakta dan opini, harus melaporkan dengan cara yang memberikan arti secara internasional, dan harus lebih dalam dari sekedar menyajikan fakta-fakta dan harus melaporkan kebenaran)

2. Media harus berfungsi sebagai forum untuk pertukaran komentar dan kritik. (Media harus menjadi sarana umum; harus memuat gagasan-gagasan yang bertentangan dengan gagasan-gagasan mereka sendiri, "sebagai dasar pelaporan yang objektif", semua "pandangan dan kepentingan yang penting" dalam masyarakat harus diwakili; media harus mengidentifikasi sumber informasi mereka karena hal ini "perlu bagi sebuah masyarakat yang bebas".

3. Media harus memproyeksikan gambaran yang benar-benar mewakili dari kelompok-kelompok konstituen dalam masyarakat. (Ketika gambaran-gambaran yang disajikan media gagal menyajikan suatu kelompok sosial dengan benar, maka pendapat disesatkan; kebenaran tentang kelompok mana pun harus benarbenar mewakili; ia harus mencakup nilai-nilai dari aspirasi-aspirasi kelompok, tetapi ia tidak boleh mengecualikan kelemahan-kelemahan dan sifa-sifat buruk kelompok)

4. Media harus menyajikan dan menjelaskan tujuan-tujuan dan nilai-nilai masyarakat. (Media adalah instrumen pendidikan, mereka harus memikul suatu tanggungjawab untuk menyatakan dan menjelaskan cita-cita yang diperjuangkan oleh masyarakat).

5. Media harus menyediakan akses penuh terhadap informasi-informasi yang tersembunyi pada suatu saat. (Ada kebutuhan untuk "pendistribusian berita dan opini secara luas") (John C Merril, 1997)

Pandangan modern tentang nilai berita menurut Walter Lippmann dalam Budyatna (2005:60-61) yaitu adanya unsur kejelasan (clarity) tentang kejadiannya, ada unsur kejutannya (surprise), ada unsur kedekatannya (proximity) secara geografis serta ada dampak (impact) dan konflik personalnya. Sedangkan Wilburt Schramm membedakan jenis-jenis berita dalam dua kelompok, yaitu yang memberikan kepuasan yang tertunda, dan yang memberikan kepuasan yang segera kepada pembaca. Yang termasuk dalam kategori kepuasan segera yaitu berita kriminal dan berita koropsi, berita kecelakaan dan bencana, olahraga dan rekreasi serta peristiwaperistiwa sosial. Sedang berita dengan kepuasan yang tertunda yaitu informasi masalah kemasyarakatan, ekonomi, sosial, ilmiah, pendidikan, keadaan cuaca dan kesehatan. 
Kriteria tentang nilai berita sekarang sudah lebih disederhanakan dan disistematikkan sehingga unsur-unsur berita yang sekarang dipakai adalah aktualitas (timeliness), kedekatan (proximity), dampak (consequence), dan humat interest. Selain itu masih ada unsur lain dalam berita yaitu magnitude. Peristiwa yang memiliki magnitude akan bernilai sebagai berita untuk layak dimuat. Magnitude dimasukkan ke dalam pengertian ketidaklaziman, misalnya karena sangat pendek atau tinggi melampaui kelaziman.

Jurnalistik atau journalisme berasal dari perkataan journal, artinya catatan harian, atau catatan mengenai kejadian sehari-hari, atau bisa juga berarti surat kabar. Journal berasal dari perkataan Latin diurnalis, artinya harian atau tiap hari. MacDougall (1972) menyebutkan bahwa journalisme adalah kegiatan menghimpun berita, mencari fakta, dan melaporkan peristiwa. Jurnalisme sangat penting di mana pun dan kapan pun. Jurnalisme sangat diperlukan dalam suatu negara demokratis.

Mats Ekstrom (2004), profesor kajian media dan komunikasi di Universitas Orebro, Swedia, mengatakan, jurnalisme adalah suatu model produksi pengetahuan sekaligus praktik komunikasi yang berkaitan dengan kepentingan dan akseptabilitas publik (public acceptance of knowledge claims). Sebagai institusi yang memproduksi ilmu pengetahuan, jurnalisme dan para wartawan aktif dalam mereproduksi realitas, serta bekerja demi memperkuat posisi pengetahuan sebagai bentuk pencerahan pemikiran.(Jurnal Komunikasi, Vol.1 Nomor 2, April 2007:149).

Jurnalisme bencana dalam penelitian ini adalah bagaimana media memberitakan bencana. Jurnalisme bencana adalah genre baru jurnalistik yang sangat penting bagi media-media di Indonesia. Pertama, secara geologis maupun sosiologis Indonesia adalah negeri rentan bencana. Kedua, media massa melalu (dan pasti) akan memberitakan setiap peristiwa bencana yang terjadi, bahkan menjadi headline ataupun mengisi waktu-waktu prime time. Ketiga, masyarakat menggantungkan pengetahuannya tentang bencana kepada informasi yang disajikan media massa. Keempat, bencana selalu diikuti ketidakpastian dan kesimpansiuran informasi, yang seringkali menyesatkan, karena itu media massa menjadi tumpuan utama untuk menyajikan informasi yang akurat. (Jurnal Komunikasi, Vol.1 Nomor 2, April 2007:149).

Liputan bencana tsunami di Aceh 2004 dan gempa bumi di Yogyakarta 2006 menimbulkan kesan bahwa ke dua kota itu luluh lantak, seakan kehancuran akibat gempa menimpa seluruh wilayah Aceh dan Yogyakarta. Dalam fase-fase demikian media seringkali menyajikan informasi yang bersifat traumatik dan dramatisasi. Yang muncul dalam pemberitaan adalah isak tangis, kesedihan, nestapa dan kisahkisah tragis lainnya. John Macmanus (1994) sosiolog media, memberikan kritik sinis, bahwa media mengekspos berbagai peristiwa bencana secara sadar dan sistematis mengikuti logika komersial (commodified). Intinya, media menanggung untung besar dalam setiap bencana. Pertama, keuntungan dari meningkatnya oplah dan rating secara tajam karena pemberitaan gempa yang dilakukan. Kedua, keuntungan kredibilitas lembaga sebagai aktor sosial penting dalam pengumpulan dan penyaluran bantuan bencana.. Bencana bukanlah bad news, melainkan good news, kisah pedih yang menghibur dan melipatgandakan keuntungan.

Ada beberapa faktor yang mempengaruhi intensitas rangsangan emosional pesan media massa. Faktor-faktor itu, antara lain, suasana emosional (mood), skema kognitif, suasana terpaan, predisposisi individual dan tingkat identifikasi khalayak 
dengan tokoh dalam media massa. Suasana emosional, menunjuk pada respon individu ketika menonton film, membaca novel, dan sebagainya. Pada saat menonton film sedih akan sangat mengharukan apabila individu mengalami kesedihan sebelumnya.. Adegan lucu akan membuat individu tertawa terbahak-bahak setelah sebelumnya individu mendapat keuntungan yang tidak disangka-sangka. Skema kognitif, terbentuk karena induksi verbal atau petunjuk pendahuluan yang menggerakkan kerangka interpretif. Suasana terpaan (setting of exposure, menunjuk pada keadaan atau suasana dimana individu berada. Predisposisi individual, mengacu pada karakteristik khas individu (Jalaluddin, 2000: 245).

Fungsi penting dari media massa adalah menginformasikan kepada masyarakat tentang sesuatu isu. McComb dan Shaw berpendapat bahwa agenda media mempunyai fungsi sebagai agenda setting. Artinya, isi (content) dari media yang dianggap penting oleh media akan menentukan apa yang akan dipikirkan oleh publik media tersebut. Dalam media cetak hal tersebut dapat dilakukan oleh media massa misalnya dengan menempatkan suatu isu dengan memberikan porsi ruang yang besar, ditempatkan dihalaman utama dan dilakukan serangkaian pemberitaan yang terus menerus tentang isu sejenis. Dalam penelitiannya Cohen menyatakan bahwa pers membuat publik memikirkan tentang sesuatu, bukan apa yang dipikirkan (what to think about, not what to think). (www.ciadvertising.org).

Sementara itu Funkhouser berpendapat bahwa hubungan antara artikel berita dengan opini publik tidaklah skedar sebagai pemuntahan kembali pendapat publik apa yang ada dalam berita, tetapi lebih pada apa yang dirasakan oleh responden itu penting. Sedangkan Takeshita mencatat bahwa media massa lebih mempunyai pengaruh atas apa yang orang pikirkan tentang iklim pendapat daripada atas apa yang mereka pikirkan tentang concern mereka sendiri (www.ciadvertising.org).

Putra (2006) dalam makalahnya Media dan Agenda-AgendaPemberdayaan Pasca Bencana menganalisis dua hal yang menjadi penyebab media begitu besar peran dan perhatiannya terhadap segala bentuk bencana. Pertama, bencana biasanya biasanya menciptakan situasi yang tidak pasti (uncertainly). Dalam situasi seperti itu, warga masyarakat akan memuncak rasa ingin tahunya. Mereka akan bertanya apa yang akan terjadi. Oleh karena itu, mereka berusaha mencari tahu jawabannya. Komunikasi terjadi karena orang ingin mengurangi ketidakpastian. Kedua, bencana bagi media merupakan even besar yang tidak bisa dilewatkan begitu saja. Sebagai satu even, bencana memiliki daya tarik yang luar biasa tanpa harus direkayasa. Bencana sendiri sudah mengandung unsur dramatik bukan buatan. Dengan kata lain, bencana memiliki nilai berita yang sangat tinggi bahkan mirip dengan sebuah cerita fiksi lengkap dengan unsur-unsur pendukungnya, seperti alur dramatik, problematika, solusi, dan aksi-reaaksi yang muncul dari berbagai karakter manusia

\section{Hubungan Timeliness Jurnalisme Bencana Banjir dan Rangsangan Emotional Mahasiswa}

Berdasarkan data hasil penelitian ini diketahui bahwa timeliness jurnalisme bencana banjir dan rangsangan emotional mahasiswa termasuk kategori tinggi. Hal tersebut ditunjukkan dengan nilai signifikansi 0,026 $<0,05$ atau ada hubunga antara timeliness jurnalisme bencana banjir sura kabar Solopos dengan rangsangan emotional mahasiswa

Tabel 1. Distribusi Jawaban Responden Mengenai Timelines $\mathbf{n}=98$ 


\begin{tabular}{clccccc}
\hline No. & \multicolumn{1}{c}{ Pernyataan } & Bobot & f & \% & Skor & Total \\
\hline 1. & Menurut saya, berita peristiwa & 5 & 22 & 22,44 & 110 & \\
banjir yang melanda Solo raya & 4 & 70 & 71,42 & 280 & \\
pada Desember 2007 & 3 & 5 & 5,10 & 15 & \\
merupakan berita actual yang & 2 & 1 & 1,04 & 2 & \\
disajikan media Solopos & 1 & - & - & - & 407 \\
\hline 2. & Berita banjir yang disajikan & 5 & 17 & 17,34 & 85 & \\
media sangat ramai & 4 & 53 & 54,08 & 212 & \\
dibicarakan dan & 3 & 24 & 24,48 & 72 & \\
diperdebatkan orang & 2 & 4 & 4,10 & 8 & 377 \\
\hline 3. & 1 & - & - & - & \\
Ketika terjadi musibah banjir, & 5 & 27 & 27,55 & 135 & \\
sloops lansung memberitakan & 4 & 63 & 64,28 & 252 & \\
keesokan harinya & 3 & 6 & 6,12 & 18 & \\
& 2 & 2 & 2,05 & 4 & \\
& 1 & - & - & - & 409 \\
\hline
\end{tabular}

Sumber: Kuesioner No. 1-3

\section{Hubungan Proximity Jurnalisme Bencana Banjir dan Rangsangan Emotional Mahasiswa}

Berdasarkan data hasil penelitian menunjukkan hasil yang belum optimal karena data tersebut menunjukkan adanya hubungan kecenderungan yang rendah terlihat dari nilai signifikan 0,864 $>0,05$ atau tidak ada hubungan antara proximity jurnalisme bencana banjir Solopos dengan rangsangan emotional mahasiswa Universitas Veteran Bangun Nusantara Sukoharjo. Rincian data hasil penelitian terlihat pada tabel berikut ini:

Tabel 2. Distribusi Jawaban Responden Mengenai Proximity $\mathbf{n}=98$

\begin{tabular}{|c|c|c|c|c|c|c|}
\hline No. & Pernyataan & Bobot & $\mathbf{f}$ & $\%$ & Skor & Total \\
\hline \multirow[t]{5}{*}{1.} & Bagi saya, berita banjir & 5 & 30 & 30,61 & 150 & \\
\hline & menarik perhatian untuk & 4 & 54 & 54,09 & 212 & \\
\hline & dibaca dan diketahui karena & 3 & 12 & 12,24 & 36 & \\
\hline & lokasinya sangat dekat dengan & 2 & 3 & 3,06 & 6 & \\
\hline & dilayah saya & 1 & - & - & - & 404 \\
\hline \multirow[t]{5}{*}{2.} & Daerah-daerah yang dilanda & 5 & 28 & 28,57 & 140 & \\
\hline & banjir merupakan daerah yang & 4 & 45 & 45,91 & 180 & \\
\hline & saya ketahui dimana posisinya, & 3 & 17 & 17,34 & 51 & \\
\hline & karena itu saya merasa perlu & 2 & 8 & 8,18 & 16 & \\
\hline & untuk membaca di surat kabar & 1 & - & - & - & 387 \\
\hline \multirow[t]{5}{*}{3.} & Sebagai sesama bangsa & 5 & 52 & 53,06 & 260 & \\
\hline & Indonesia, saya merasa sedih & 4 & 42 & 42,85 & 168 & \\
\hline & dengan terjadinya musibah kali & 3 & 4 & 4,09 & 12 & \\
\hline & ini & 2 & - & - & - & \\
\hline & & 1 & - & - & - & 440 \\
\hline & Menurut saya, berita banjir & 5 & 35 & 35,71 & 175 & \\
\hline & merupakan musibah yang & 4 & 35 & 35,71 & 140 & \\
\hline
\end{tabular}




\begin{tabular}{|c|c|c|c|c|c|c|}
\hline No. & Pernyataan & Bobot & $\mathbf{f}$ & $\%$ & Skor & Total \\
\hline & datangnya dari Sang Pencipta, & 3 & 9 & 9,18 & 27 & \\
\hline & karena itu kita harus & 2 & 13 & 13,26 & 26 & \\
\hline & $\begin{array}{l}\text { menerimanya dengan sabar } \\
\text { dan tabah }\end{array}$ & 1 & 6 & 6,14 & 6 & 374 \\
\hline \multirow[t]{6}{*}{5.} & Sudah seharusnya Solopos & 5 & 22 & 22,44 & 110 & \\
\hline & menyajikan berita banjir yang & 4 & 54 & 55,10 & 216 & \\
\hline & terjadi di Solo Raya karena & 3 & 15 & 15,30 & 45 & \\
\hline & lokasi Solopos dan lokasi & 2 & 5 & 5,10 & 10 & \\
\hline & $\begin{array}{l}\text { bencana banjir berada dalam } \\
\text { satu wilayah }\end{array}$ & 1 & 2 & 2,06 & 2 & 383 \\
\hline & & \multicolumn{4}{|c|}{ Jumlah } & 1.988 \\
\hline
\end{tabular}

Sumber: Kuesioner No. 4-8

\section{Hubungan Concequence Jurnalistik Bencana Banjir dan Rangsangan Emotional Mahasiswa}

Hubungan antara nilai berita concequence jurnalisme bencana banjir dengan rangsangan emotional mahasiswa Universitas Veteran Bangun Nusantara Sukoharjo cenderung tinggi. Hal ini terlihat dari nilai signifikan $0,000<0,05$ atau ada hubungan antara nilai berita concequence jurnalisme bencana banjir dengan rangsangan emotional mahasiswa. Rincian data hasil penelitian terlihat pada tabel berikut ini:

Tabel 3. Distribusi Jawaban Responden Mengenai Consequence $\mathbf{n}=98$

\begin{tabular}{|c|c|c|c|c|c|c|}
\hline No. & Pernyataan & Bobot & $\mathbf{f}$ & $\%$ & Skor & Total \\
\hline \multirow[t]{5}{*}{1.} & Menurut saya, dampak yang & 5 & 48 & 48,97 & 240 & \\
\hline & ditimbulkan akibat banjir & 4 & 44 & 44,89 & 176 & \\
\hline & sangat luas baik dari segi & 3 & 3 & 3,07 & 9 & \\
\hline & ekonomi, sosial dan & 2 & 3 & 3,07 & 6 & \\
\hline & sebagainya & 1 & - & - & - & 431 \\
\hline \multirow[t]{5}{*}{2.} & Akibat banjir banyak warga & 5 & 30 & 30,60 & 150 & \\
\hline & yang mengungsi ke tempat & 4 & 60 & 61,22 & 240 & \\
\hline & lain dan mendirikan tenda- & 3 & 7 & 7,14 & 21 & \\
\hline & tenda sementara & 2 & 1 & 1,04 & 2 & \\
\hline & & 1 & - & - & - & 413 \\
\hline \multirow[t]{5}{*}{3.} & Banjir mengakibatkan & 5 & 32 & 32,65 & 160 & \\
\hline & banyak pihak yang terlibat & 4 & 59 & 60,20 & 236 & \\
\hline & untuk bersatu & 3 & 7 & 7,15 & 21 & \\
\hline & menanggulangi musibah & 2 & - & - & - & \\
\hline & tersebut & 1 & - & - & - & 417 \\
\hline \multirow[t]{5}{*}{4.} & Banjir yang terjadi Desember & 5 & 7 & 7,14 & 35 & \\
\hline & tahun lalu akibat dari & 4 & 31 & 31,63 & 124 & \\
\hline & tindakan atau kebijakan, & 3 & 28 & 28,57 & 84 & \\
\hline & terkait dengan dibukanya & 2 & 25 & 25,51 & 50 & \\
\hline & $\begin{array}{l}\text { pintu waduk Gajah Mugkur } \\
\text { Wonogiri }\end{array}$ & 1 & 7 & 7,15 & 7 & 300 \\
\hline \multirow[t]{2}{*}{5.} & Banjir juga disebabkan & 5 & 35 & 35,71 & 175 & \\
\hline & banyaknya saluran air yang & 4 & 55 & 56,12 & 220 & \\
\hline
\end{tabular}




\begin{tabular}{|c|c|c|c|c|c|}
\hline Pernyataan & Bobot & $\mathbf{f}$ & $\%$ & Skor & Total \\
\hline tersumbat karena kelalaian & 3 & 6 & 6,12 & 18 & \\
\hline warga & 2 & 2 & 2,05 & 4 & \\
\hline & 1 & - & - & - & 417 \\
\hline & \multicolumn{4}{|c|}{ Jumlah } & 1.978 \\
\hline
\end{tabular}

Sumber: Kuesioner No. 9-13

\section{Hubungan Human Interest Jurnalisme Bencana Banjir dan Rangsangan Emotional Mahasiswa}

Dugaan adanya kecenderungan hubungan antara nilai berita human interest jurnalisme bencana banjir terhadap rangsangan emosional mahasiswa Universitas Veteran Bangun Nusantara Sukoharjo cenderung tinggi. Hal tersebut ditunjukkan dengan nilai signifikansi $0,000<0,05$ atau ada hubungan antara nilai berita human interest jurnalisme bencana banjir dengan rangsangan emosional mahasiswa. Lebih lanjut rincian data hasil penelitian terlihat pada tabel berikut ini:

Tabel 4. Distribusi Jawaban Responden Mengenai Human Interset $\mathrm{n}=98$

\begin{tabular}{|c|c|c|c|c|c|c|}
\hline No. & Pernyataan & Bobot & $\mathbf{f}$ & $\%$ & Skor & Total \\
\hline \multirow[t]{5}{*}{1.} & Saya sedih melibat & 5 & 30 & 30,61 & 150 & \\
\hline & banyaknya korban banj̈ir & 4 & 60 & 61,22 & 240 & \\
\hline & & 3 & 7 & 7,14 & 21 & \\
\hline & & 2 & 1 & 1,03 & 2 & \\
\hline & & 1 & - & - & - & 413 \\
\hline \multirow[t]{5}{*}{2.} & Para korban banjir harus & 5 & 57 & 58,16 & 285 & \\
\hline & segera mendapat & 4 & 38 & 38,77 & 152 & \\
\hline & pertolongan/bantuan dari & 3 & 1 & 1,03 & 3 & \\
\hline & berbagai pihak & 2 & 2 & 2,04 & 4 & \\
\hline & & 1 & - & - & - & 444 \\
\hline \multirow[t]{5}{*}{3.} & Menurut saya, jika korban & 5 & 30 & 30,62 & 150 & \\
\hline & banjï tidak segera & 4 & 48 & 48,97 & 192 & \\
\hline & mendapat pertolongan maka & 3 & 16 & 16,32 & 48 & \\
\hline & akan menimbulkan & 2 & 4 & 4,09 & 8 & \\
\hline & $\begin{array}{l}\text { konflik/ketegangan yang } \\
\text { serius }\end{array}$ & 1 & - & - & - & 398 \\
\hline \multirow[t]{5}{*}{4.} & Saya merasa simpati dengan & 5 & 31 & 31,63 & 155 & \\
\hline & para korban banjï, dan & 4 & 60 & 61,22 & 240 & \\
\hline & seandainya bisa, sayaingin & 3 & 7 & 7,15 & 21 & \\
\hline & membantu mereka dengan & 2 & - & - & _ & \\
\hline & sekuat tenaga & 1 & - & - & - & 416 \\
\hline \multirow[t]{6}{*}{5.} & Saya tidak menduga sama & 5 & 23 & 23,46 & 115 & \\
\hline & sekali, banjir tahun lalu & 4 & 41 & 41,83 & 164 & \\
\hline & menimbulkan banyak & 3 & 28 & 28,57 & 84 & \\
\hline & korban (harta benda) & 2 & 6 & 6,14 & 12 & \\
\hline & $\begin{array}{l}\text { dibandingkan tahun-tahun } \\
\text { sebelumnya }\end{array}$ & 1 & - & - & - & 375 \\
\hline & & \multicolumn{4}{|c|}{ Jumlah } & 2.046 \\
\hline
\end{tabular}


Sumber: Kuesioner No. 14-18

\section{Hubungan Magnitude Jurnalisme Bencana Banjir dan Rangsangan Emotional Mahasiswa}

Terdapat kecenderungan hubungan antara nilai berita magnitude jurnalisme bencana banjir dengan rangsangan emosinal mahasiswa. Diketahuinya kecenderungan hubungan tersebut bersandar kepada hasil uji statistik yaitu dengan nilai signifikansi $0,000<0,05$ atau ada hubungan antara nilai berita magnitude jurnalisme bencana banjir dengan rangsangan emosional mahasiswa. Lebih lanjut rincian data hasil penelitian terlihat pada tabel berikut ini:

Tabel 5. Distribusi Jawaban Responden Mengenai Magnitude $\mathbf{n}=98$

\begin{tabular}{|c|c|c|c|c|c|c|}
\hline No. & Pernyataan & Bobot & $\mathbf{f}$ & $\%$ & Skor & Total \\
\hline \multirow[t]{5}{*}{1.} & Banyak rumah penduduk & 5 & 20 & 20,40 & 100 & \\
\hline & yang tenggelam akibat banjir & 4 & 55 & 56,13 & 220 & \\
\hline & & 3 & 14 & 14,28 & 42 & \\
\hline & & 2 & 9 & 9,19 & 18 & \\
\hline & & 1 & - & - & - & 380 \\
\hline \multirow[t]{5}{*}{2.} & Banyak warga yang tiba-tiba & 5 & 19 & 19,38 & 95 & \\
\hline & kehilangan harta benda yang & 4 & 59 & 60,20 & 236 & \\
\hline & dimilikinya & 3 & 16 & 16,32 & 48 & \\
\hline & & 2 & 4 & 4,10 & 8 & \\
\hline & & 1 & - & - & - & 387 \\
\hline \multirow[t]{6}{*}{3.} & Banjir secara merata & 5 & 22 & 22,44 & 110 & \\
\hline & melanda Solo Raya (Solo. & 4 & 43 & 43,88 & 172 & \\
\hline & Karanganyar, Sragen, & 3 & 24 & 24,48 & 72 & \\
\hline & Boyolali, Klaten, Wonogiri). & 2 & 8 & 8,16 & 16 & \\
\hline & $\begin{array}{l}\text { Menurut saya, hal tersebut } \\
\text { sangat berbeda pada tahun- } \\
\text { tahun sebelumnya }\end{array}$ & 1 & 1 & 1,04 & 1 & 371 \\
\hline & & & Ju & & & 1.138 \\
\hline
\end{tabular}

Sumber: Kuesioner No. 19-21

\section{KESIMPULAN}

Nilai berita timeliness jurnalisme berita bencana surat kabar Solopos dalam mempengaruhi rangsangan emosional mahasiswa Universitas Veteran Bangun Nusantara Sukoharjo cenderung tinggi. Timeliness atau aktualitas berita yang disajikan Solopos merupakan peristiwa yang benar-benar baru terjadi dan perlu diketahui pembaca dan dengan adanya berita mengenai bencana banjir yang melanda Solo Raya maka menimbulkan rangsangan-ransangan emosional pada diri mahasiswa.

Nila berita proximity jurnalisme berita bencana surat kabar Solopos dalam mempengaruhi rangsangan emosional mahasiswa Universitas Veteran Bangun Nusantara Sukoharjo cenderung rendah. Hal ini lebih disebabkan karena faktor kedekatan secara geografis dan psikologis. Secara geografis, meskipun kampus Univet Bantara berada dalam wilayah Solo Raya tetapi sebagian mahasiswa bertempat 
tinggal di luar wilayah dan bahkan mungkin tidak berada dalam lokasi banjir. Karena itu nilai berita proximity kurang memberikan rangsangan emosional kepada responden. Secara psikologis, lebih disebabkan karena tidak adanya hubungan emosional antara wilayah banjir dengan sikap predisposisi individu mahasiswa sehingga kurang memberikan perhatian yang intens.

Nila berita consequence jurnalisme berita bencana surat kabar Solopos dalam mempengaruhi rangsangan emosional mahasiswa Universitas Veteran Bangun Nusantara Sukoharjo cenderung tinggi. Hal ini disebabkan karena dampaknya yang sangat luar biasa (misalnya: banyaknya korban, banyaknya kerugian, dan sebagainya) sehingga menimbulkan rangsangan emosinal terhadap mahasiwa, seperti sikap terkejut, heran, tidak terduga, dan sebagainya.

Nila berita human interest jurnalisme berita bencana surat kabar Solopos dalam mempengaruhi rangsangan emosional mahasiswa Universitas Veteran Bangun Nusantara Sukoharjo cenderung tinggi. Pemberitaan Solopos terkait dengan masalah banjir sering menyajikan berita-berita yang menyentuh hati nurani pembaca sehingga menimbulkan rangsangan emosional terhadap mahasiswa.

Nila berita magnitude jurnalisme berita bencana surat kabar Solopos dalam mempengaruhi rangsangan emosional mahasiswa Universitas Veteran Bangun Nusantara Sukoharjo cenderung tinggi. Bajir yang yang terjadi di akhir tahun 2007 memang sangat berbeda pada tahun-tahun sebelumnya sehingga peristiwa tersebut merupakan peristiwa yang luar biasa dan karena ketidak laziman inilah mempengaruhi emosional mahasiswa.

\section{DAFTAR PUSTAKA}

Ahmadi T. 1977. Sistem Pers Pancasila 1966-1974. Yogyakarta: LKiS.

Anwar, Saifuddin, 1986. Reliabilitas Dan Validitas Interpretasi dan Komputasi. Yogyakartra: Liberty

Budyatna, Muhammad,. 2005. Jurnalistik Teori \& Praktik. Bandung: Remaja Rosdakarya

Deddy Iskandar Muda. 2003. Jurnalistik Televisi Menjadi Reporter Profesional. Bandung: PT Remaja Rosdakarya

Eriyanto.2001. Analisis Wacana: Pengantar Analisis Teks Media. Yogyakarta: LKiS

Fisher, Aubrey. 1986. Teori-Teori Komunikasi. Soejono Trimo (penerj). Bandung: Remaja Rosdakarya.

Hajar, Ibnu. 1996. Dasar-Dasar Metodologi Penelitian Kuantitatif Dalam Pendidikan. Jakarta: Raja Grafindo Persada.

MacDougall, Curtis D. 1972. Interpretative Reporting. Macmillan Publishing Co., Inc. New York 
Masduki dan Bambang Muryanto, "Jurnalisme Publik pada Media Penyiaran Publik", Jurnal Komunikasi. Volume 1, Nomor 2, April 2007. Progdi Ilmu Komunikasi Universitas Islam Indonesia. Yogyakarta

McQuail, Dennis. 1992. Media Performance. London: Sage Publications.

Merril, John C. 1997. Journalism Ethics-Philosophical Foundations for News Media. St. Martin's Press. New York

Nazaruddin, Muzayin, "Jurnalisme Bencana: Sebuah Tinjauan Etis", Jurnal Komunikasi. Volume 1, Nomor 2, April 2007. Progdi Ilmu Komunikasi Universitas Islam Indonesia. Yogyakarta

Nazir, Moh. 1988. Metode Penelitian, Jakarta: Ghalia Indonesia

Putra, I Gusti Ngurah. 2006. "Media dan Agenda-Agenda Pemberdayaan Pasca Bencana: Memaksimalkan Fungsi Watchdog". Makalah. Disampaikan dalam Seminar Media, Solidaritas Sosial, dan Proses Rekonstruksi Pasca Bencana yang diselenggarakan Jurusan Ilmu Komunikasi FISIPOL UGM dan Yayasan SET di Ruang Seminar FISIPOL UGM, 09 Agustus 2006.

Rakhmat, Jalaluddin. 2000. Psikologi Komunikasi, Bandung: Remaja Rosdakarya

Slamet, Yulius. 2001. Teknik Pengambilan Sampel Untuk Penelitian Kuantitatif dan Kualitatif. Surakarta.

Septiawan Santana K, 2005. Jurnalisme Kontemporer. Jakarrta: Yayasan Obor Indonesia

Yusuf, Iwan Awaluddin, ”Ada Kuis di Tengah Gempa: Membangun Epistemologi Liputan Bencana di Media", Jurnal Komunikasi. Volume 1, Nomor 1, Oktober 2006. Progdi Ilmu Komunikasi Universitas Islam Indonesia. Yogyakarta 